IRA-International Journal of Technology \& Engineering ISSN 2455-4480; Vol.07, Issue 02 (2017)

Pg. no. 17-27

Institute of Research Advances

http://research-advances.org/index.php/IRAJTE

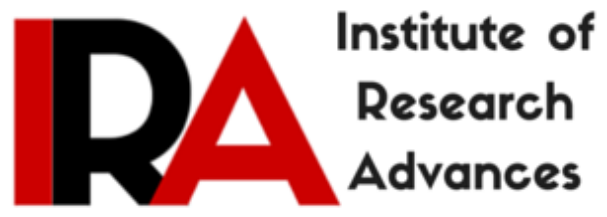

\title{
Solution to Avoid Power Crisis in Telangana State by Implanting Non Convectional Energy
}

\author{
Mohammed Dilawar \\ Assistant Professor, Mechanical Engineering, Guru Nanak Institutions Technical Campus, \\ Telangana, India. \\ Mohammed Arif Hussain \\ Associate Professor, Mechanical Engineering, Guru Nanak Institutions Technical Campus, \\ Telangana, India. \\ Mohammed Akram Ullah Khan \\ Assistant Professor, Mechanical Engineering, Guru Nanak Institutions Technical Campus, \\ Telangana, India.
}

Type of Reviewed: Peer Reviewed.

DOI: http://dx.doi.org/10.21013/jte.v7.n2.p2

\section{How to cite this paper:}

Dilawar, M., Hussain, M., \& Khan, M. (2017). Solution to Avoid Power Crisis in Telangana State by Implanting Non Convectional Energy. IRA-International Journal of Technology \& Engineering (ISSN 2455-4480), 7(2), 17-27. doi:http://dx.doi.org/10.21013/jte.v7.n2.p2

(C) Institute of Research Advances

\section{(c) B EY-NC}

This work is licensed under a Creative Commons Attribution-Non Commercial 4.0 International License subject to proper citation to the publication source of the work.

Disclaimer: The scholarly papers as reviewed and published by the Institute of Research Advances (IRA) are the views and opinions of their respective authors and are not the views or opinions of the IRA. The IRA disclaims of any harm or loss caused due to the published content to any party. 


\section{ABSTRACT}

Perennial Efforts to combat power crises in newly found Telangana state, compelled to use hybrid source of power which is being catered to facilitate the needs of modern trends, life style, multinational business requirements which enforced the need to explore the modern application of solar energy run household and administrative block. Air conditioning requirement, which consumes more than 30\% of the state procured power from different sources, which can be save and utilize for agriculture sector and other constructive needs.

In Telangana State every commercial, administrative and elite residential block is equipped with air conditioning system where the temperature ranges between $32-43^{\circ} \mathrm{C}$ in summer season. Telangana State is attracting the world class business investors. This design can caters the world class needs therefore this paper explore the design and performance of solar power air-conditioning system, which is integrated with invertors, PV panels, solar charger and batteries. This design can be used in non-electrified rural arid areas to avoid the expenses of supplying electricity.

This research project begins with the cooling load calculations for the selected space ideally whose dimensions are assumed to be one tone of refrigeration $(3.5 \mathrm{~kW})$. Considering the basic parameters of cooling the photovoltaic cells has been deduced and necessary connections are arranged.

To acquire the inlet and outlet temperatures of compressor, evaporator and condenser, data logging procedure is employed. The input power for this system as well as coefficient of performance for above said climatic conditions can be deduced. The COP varies from two to four for this system and these results are compared with the convectional system performance they both match with each other considerably.

Key Words: Solar Energy, Performance, Arid Areas, COP, Climatic Conditions.

\section{Introduction}

After the formation of Telangana state the demand for the power especially in refrigeration system has dramatically increased. The major reasons for the increase in power consumption is due to following reasons such as population explosion, life style, increasing day to day needs, the architectural design of the residential and commercial buildings, all these parameters contributes in this regards. This provides a greater blow to the development and progress of the state.

Due to peek rise in power consumption leads to abrupt power failures and insufficient power supply. This may be handled by using solar power panels hybridized with PV batteries which can shoot out the above said problem. It is the best alternative which has least impact on the environment as well as on operational expenditure.

\section{LITERATURE REVIEW}

Extensive research has been conducted in this regard especially in those countries where there is abundant sunlight. Such as Middle East, African, European and Asian countries carried out extensive research and implemented them out of which few outstanding research works are mentioned here. Saigh 1981 [1] listed out the correlations for a hot arid climate like desert country. He made four solar air-conditioning systems. Mattarola (1982) [2] carried out a general survey of solar power airconditioning methods together with description of a regular open cycle absorption cooler and dehumidification programs. Sun powered air-conditioning procedure was once design, installed and operated in Singapore, (Bong, 1987 [3]). Ali and fathalah (1988) [4] awarded a joined absorption desiccant excessive performance air-conditioning system reasonable for sizzling muggy areas. Feasibility of utilising solar vigor for remedy cooling in Hong Kong has been studied, a solar powered absorption air-conditioning process used to be design and effectively constructed on the campus of the university of Hong Kong (yeung, 1992)[5]). T silingiris (1993)[6] carried out the progress of a theoretical microcomputer model cheap for execution forecasts and examination of the operational behavior of a simple sunlight cooling procedure for little confidential applications. A hybrid open- 
cycle vapor absorption and fluid desiccant framework utilizing $\mathrm{LiBr}$ for the procedure of assimilation and dehumidification has been simulated and the COP so bought is around $50 \%$ bigger than that of traditional vapor absorption (Khalid Ahmed et al., 1997 [7]). Li and Sumathy (2000) [8] checked on solar-powered air-conditioning frameworks with the absorption air of lithium bromide and water. Quite a lot of endeavors have been made by experts to increase the execution of the sun applied airconditioning (chiller) subsystems. The achievability of sun-powered absorption cooling innovation under Tunisian conditions has been completed (MoncefBalghouthi, 2005 [9]). Mittal et al. (2005) [10] awarded a work with a view to support numerous experts work within the field of air conditioning and furnish them with major studying on absorption frameworks. Sayigh (2007) [11] directed the hypothetical conduct of warm parameters and their interplay in absorption cooling frameworks managed with sun power. Constantinos et al. (2007) [12] portrayed the principal consequences of the european enterprise SACE (solar air conditioning in Europe), deliberate to review the state-of-the-art, future desires and normal possibilities of solar cooling in Europe. Solar-powered absorption air conditioning system was planned and introduced in the green building of Shanghai Research Institute of Building Science (Zhai et al., 2008 [13]). Umberto et al. (2009) [14] examined the specialised and monetary practicality of sun absorption cooling applications, supposed for two distinctive application fields: trendy refrigeration and air-con. Paula Naukkarinen (2009) [15] mentioned the sunlight air-con and its role in alleviating the vigour difficulty of the Mediterranean lodgings. Koroneos.Et al. (2010) [16] researched the utilization of thermal sun framework inside the scientific Centre applications. A sun situated cross breed desiccant ventilating structure has been organized, likely investigated and speculatively researched (Dong La et al., 2011 [17]). The competencies functions and benefits of powering sunlight air-conditioning programs making use of concentrator enlarged solar powered gatherer (Dan et al., 2012 [18]). Lavinia and Mario (2012) [19] inquired about the sunlight based warming and ventilating by GSHP coupled to PV system for a consumption compelling high-vitality execution building. Ahmed H Abdel Salam and Carey J Simonson (2014) [20] initiate a membrane liquid desiccant air conditioning (MLDAC). Ha Q P and Vakiloroaya V (2014)[21] considered the execution update and vitality adequacy change of another crossover sun powered helped aerating and cooling framework.

It can be seen that numerous specialists led sun oriented cooling and sun oriented controlled aerating and cooling frameworks yet none of these led the capability of sun based power ventilation system in Telangana state notwithstanding its climatic conditions, which is the inspiration of this work. This project will concentrate on the plan and development of sun oriented controlled ventilating framework coordinated with photovoltaic (PV) framework which is easy to use in Telangana state and the nonelectrified remote ranges in Telangana state where the force of sun based radiation scopes to 5.218 $\mathrm{kWh} / \mathrm{m} 2 /$ day.In this work, the outline of the sunlight based fueled aerating and cooling framework is portrayed in detail and its execution over a whole cooling season will be examined by using the PV boards to create vital power for little scale air-conditioning system around 1 TR and contrast the framework performance and the customary system.

\section{SOLAR RESOURCE OF INDIA}

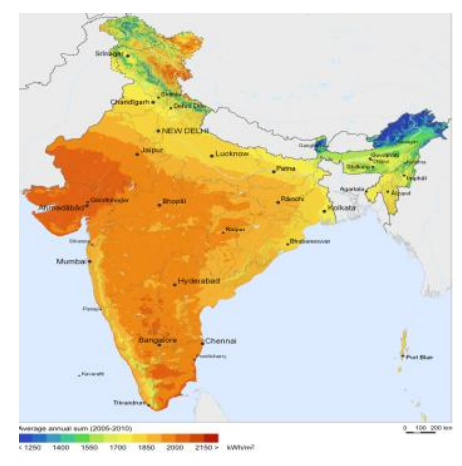

Figure 1: Average annual sum (2005-2010) 


\section{SOLAR IRRADIATION IN TELANGANA, INDIA}

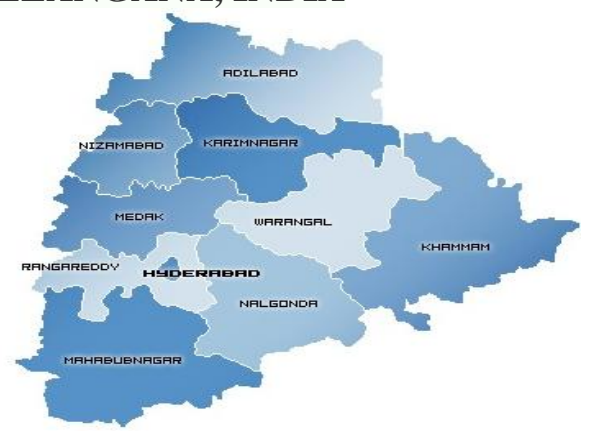

Figure 2: Political Map of Telangana State period 2015-2016

In this above figure, the whole Telangana State lies across 17.4 degree latitude which is considered as moderate arid region with ample solar radiation which can be utilize throughout the year as shown in the index table below.

Table: 1 showing the Reading of Monthly Radiation

\begin{tabular}{|c|c|}
\hline \multicolumn{2}{|c|}{ SOLAR RADIATION } \\
\hline \multicolumn{2}{|c|}{ Average annual: 5.21833 $\mathrm{kWh} / \mathrm{m}^{2} /$ day } \\
\hline \multicolumn{2}{|c|}{ Monthly Average } \\
\hline January & 5.06 \\
\hline February & 5.82 \\
\hline March & 6.36 \\
\hline April & 6.77 \\
\hline May & 6.43 \\
\hline June & 4.84 \\
\hline July & 4.26 \\
\hline August & 4.18 \\
\hline September & 4.52 \\
\hline October & 4.79 \\
\hline November & 4.85 \\
\hline December & 4.74 \\
\hline
\end{tabular}

\section{Solar Radiation}

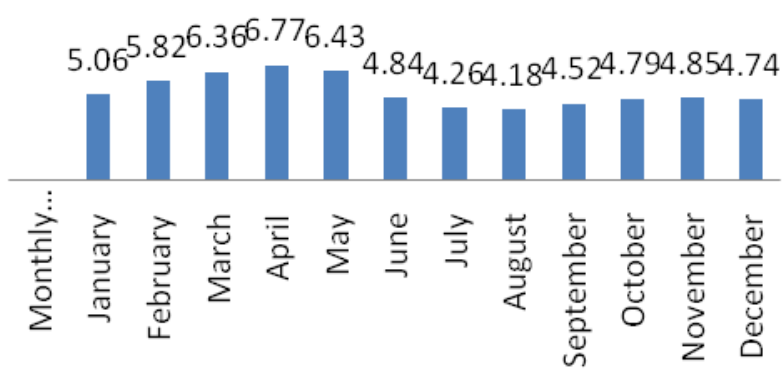

Chart-1: The above chart bar shows the variation in Solar Radiation 


\section{PROCEDURE AND EQUIPMENTS}

Most sophisticated instruments were utilized to minimize the PV system along with battery storage. The procedure adopted for the analyses as follows

\section{REVELENT DATA COLLECTION FROM THE METROLOGICAL SITE}

Data for the analysis of load calculations are design temperature, humidity, daily and annual values of solar radiation, working hours, Tilt Angle.

\section{DETERMINATION OF LOAD}

Load can be determined by considering the ideal space working hour's ambient temperature and the desired temperature in the present case. The ambient temperature is considered as $450 \mathrm{C}$ with $50 \%$ relative humidity and 220C. By using Hourly Analysis Program (HAP) the results are displayed chronological order. From the graph it can be deduced that the maximum cooling required during of April-May. Experimental load by using HAP was about $3.5 \mathrm{~kW}$, minimum $2.5 \mathrm{~kW}$.

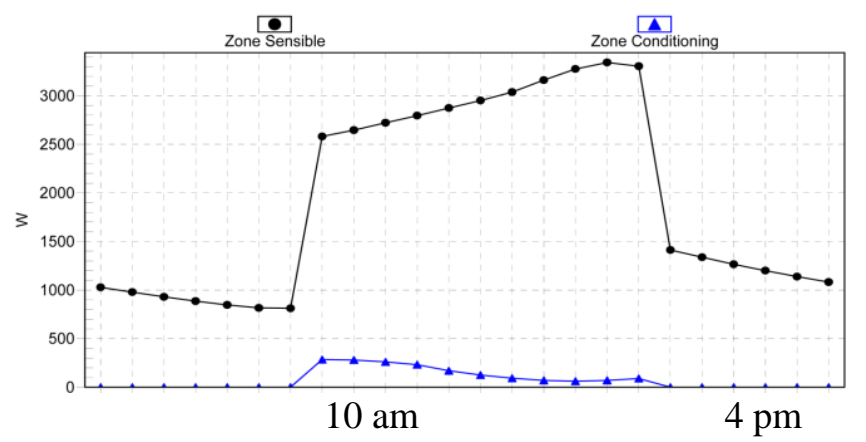

Figure 3: Optimum load during office hours during April-May

\section{SELECTION OF COOLING UNIT BASED ON DESIGN PARAMETERS}

The specifications of the cooling unit relevant parameters are equivalent to $3.5 \mathrm{~kW}$ capacity with 220 $\mathrm{V}, 150 \mathrm{~A}$ with power input $1300 \mathrm{~W}$ to $1400 \mathrm{~W}$ which provides the most suitable COP.

\section{SOLAR PHOTOVOLTAIC}

Photovoltaic has been gotten from the blend of two words, "Photograph" and "Voltaic". Photograph implies light and voltaic means power. It is a procedure that believers light specifically into power. Photovoltaic material, most generally very cleaned silicon changes over daylight straightforwardly into power

\section{SELECTION AND DESIGN OF PV SYSTEM}

Sunlight based cells are utilized to change over light into power. A PV framework comprises of PV modules and balance of systems (BOS). Equalization of frameworks incorporates module bolster structure, stockpiling, wiring, power, gadgets and so on.

DC (direct current) power is produced when sun oriented radiation strikes the PV module. Force can be utilized as a part of any DC stack straightforwardly amid this era. Be that as it may, the era exists amid daytime. Along these lines, some stockpiling gadget is expected to run the framework around evening time or in low daylight hour. Again this force can't be utilized to run any AC (alternate current) load. Inverter must be utilized to change over DC into AC. 
Sun oriented PV frameworks are classes into

- Stand-alone PV frameworks (and also called as off grid systems)

- Grid associated PV frameworks (additionally approached on grid systems)

- Hybrid frameworks

\section{STAND-SOLITARY-PV-SYSTEMS}

Remain solitary frameworks are not associated with utility electrical cables and these are independent frameworks. These frameworks could either be utilized to charge the batteries that serve as a vitality stockpiling gadget or could work specifically utilizing the sunlight based vitality accessible as a part of the daytimes. These frameworks comprise of the accompanying:

- Solar boards mounted on the rooftop or in open spaces. Photovoltaic modules deliver direct current (DC) electrical force.

- Batteries to store DC vitality produced by the sun powered boards.

- Charge controller to avert overcharging the battery.

- Inverter to change over power delivered by the framework from DC to AC power.

The accompanying outline indicates PV framework driving AC loads with battery bank. DC burdens can likewise be associated straightforwardly to the battery bank. It is additionally conceivable to control the AC load without battery, however all things considered it would be bound just to daytime when sun powered radiation is adequate to create required power.

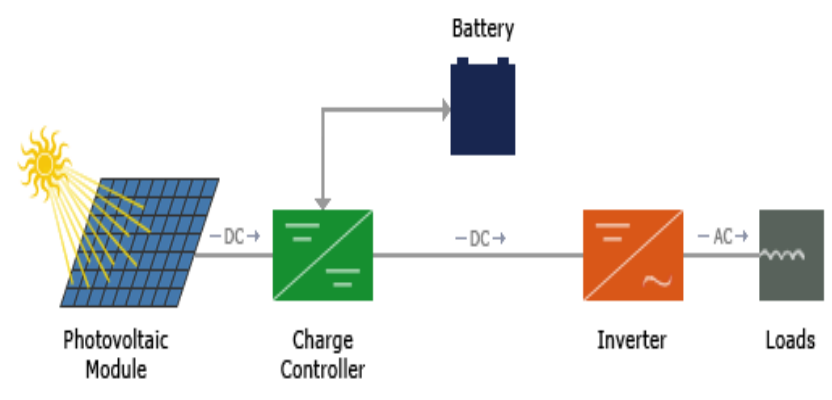

Figure 4: Flow diagram of the PV system

\section{CALCULATIONS}

The charger controller specifications are $12 \mathrm{~V}$, charging rate control $24 \mathrm{Amp}$

Here, a voltage regulator is designed to maintain automatically a constant voltage level.

(C.O.P) cooling $=$ Desired Output/Input Power

Input power $=3.5 \mathrm{~kW} / 2.5$

$$
\text { Input power }=1.4 \mathrm{~kW}
$$

Where the adequate COP of the framework suggested by the provider ought to be 2.5

Input range power lies between 1.2 to $1.4 \mathrm{~kW}$

Power required present case is $1.4 \mathrm{~kW}$ for eight working hour per day

Work $*$ working hours in day $=$ work hours every day 
$1.4 \times 8=11.2 \mathrm{~kW}$ hr/day

Optimum productive sunlight available per day $=6 \mathrm{hr} /$ day

Total load capacity $=$ work per day / Optimum hours of sunlight per day

Total load capacity $=11.2 \mathrm{~kW}$ hr per day $/ 6 \mathrm{hr}$ per day

$$
=1.87 \mathrm{~kW}
$$

Based down above calculations the PV solar system of capacity $1.87 \mathrm{~kW}$ is required

The available size of PV panel with standard $300 \mathrm{~W}$ output

Number of panels $=$ Total capacity $/$ the output for one panel

$$
=1.87 \mathrm{~kW} / 0.3 \mathrm{~kW}=6 \text { panels }
$$

Based on practical application a $40 \%$ voltage drop is assumed

Assuming drop voltage $40 \%$

$150 \times 40 \%=60$ A.h

The minimum efficiency of the battery is $80 \%$

The actual Ampere of the battery is $(150 \times 80 \%)-60=60$ A.h

The actual capacity of one battery that is 60 A.h, working hours is eight

The actual Amp $=60$ A.h $/ 8 \mathrm{~h}=7.5 \mathrm{~A}$

The running current of air conditioning unit is $5.68-7.5$ A with beginning current of $30 \mathrm{Amp}$

Number of battery $=30 \mathrm{~A} / 7.5 \mathrm{~A}$

$$
=4 \text { batteries for eight hours }
$$

Number of batteries for two days $=4 \times 48 \mathrm{~h} / 8 \mathrm{~h}$

$=24$ batteries

With total power stored $1.87 \mathrm{~kW}, 12$ volt, and $150 \mathrm{Ah}$.

The inverter determinations are, DC input $48 \mathrm{~V}$, AC output $220-240 \mathrm{~V}$, output control $5 \mathrm{~kW}$ and the charger controller 12 volts each and accuse rating 24 Amperes of over load and short out assurance.

\section{OPTIMUM TILT OF SOLAR PANELS}

Boards gather sun powered radiation straightforwardly from the sun, from the sky, and from daylight reflected off the ground or region encompassing the PV board. Arranging the PV board in a heading and tilt to augment its introduction to direct daylight will improve the accumulation productivity. The board will gather sun based radiation most productively when the sun's beams are opposite to the board's surface. The point of the sun changes consistently. In this manner, the ideal tilt plot for a PV board in the winter will contrast from the ideal tilt plot for the mid year. This edge will likewise shift by latitude

The Optimum tilt angle at Hyderabad ranges from 50 to 960 during winter and summer months respectively, as shown in figure below. 


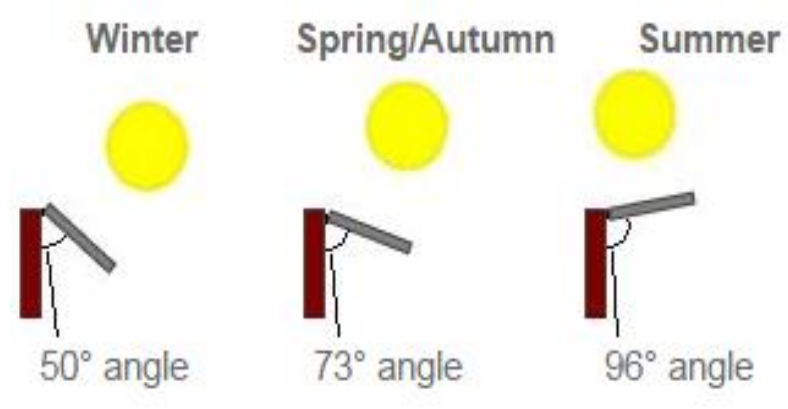

Figure 5: Figures Shown in degrees from vertical

\section{RESULT ANALYSIS}

The operation of the Air-conditioning system is to ingest the warmth from the space and keeping up attractive inside climatic conditions as indicated by human solace, regardless of outside conditions. There are different sorts of ventilating frameworks at the same time, the most widely recognized sort vapor compression refrigeration framework is prescribed. It comprises of compressor, condenser, expansion gadget, and evaporator. Compressor is electrically worked can be depicted as the heart of air-conditioning framework as it pump refrigerant all through the framework. The capacity of the compressor is to get low pressure and temperature vapor refrigerant from the evaporator and compressed to a high pressure and temperature vapor refrigerant is released into the condenser. The refrigerant while going through the condenser, surrenders its dormant warmth to the encompassing from the open air unit. The warm liquid is fed to the expansion valve, where the both pressure, temperature decreases and carried back to the evaporator. In this, VCR system R-22 used as a refrigerant

System performance was evaluated by using data logging system. The data pertaining to the months of February, April, may between 9.am to 4.pm the results obtained are presented in the form graphs below.

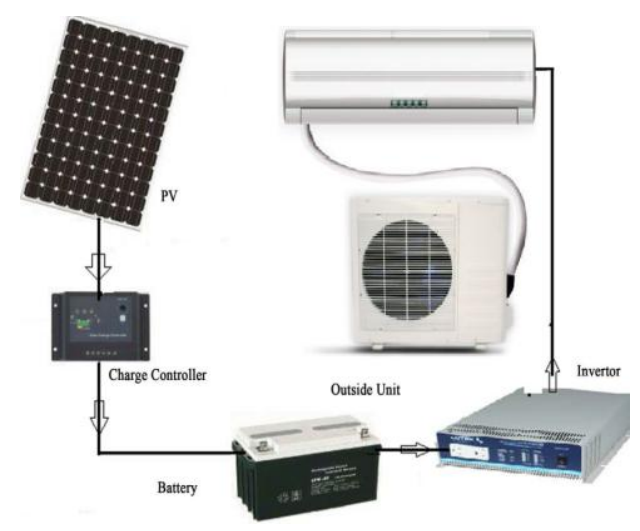

Figure 6: Layout the Air-conditioning system 
VOPOUR COMPRESSION REFRIGERATION CYLE BY USING T-S AND P-H DIAGRAM

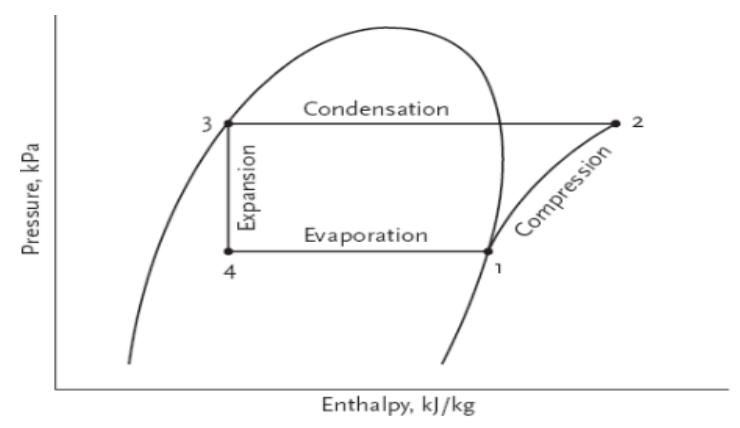

Figure 7: Show the P-H diagram

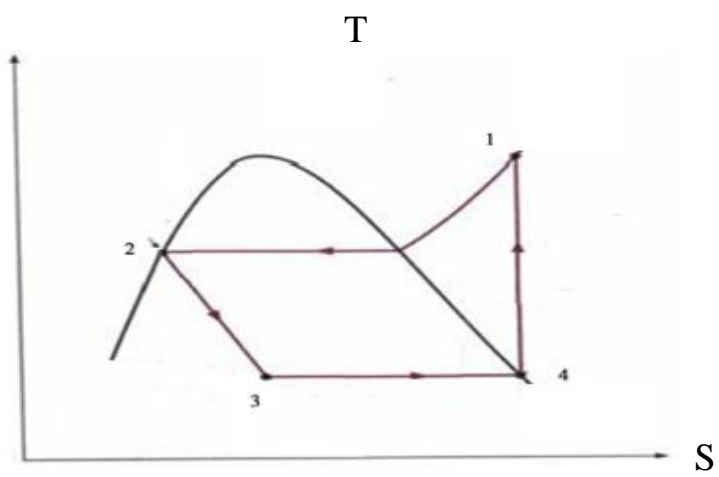

Figure 8: Show the Temp-Entropy diagram

From the figure the points from one to four can be described as follow

$\mathrm{T} 1=$ Outlet temperature of the compressor where the refrigerant eject the compressor as superheated vapour

$\mathrm{T} 2=$ Outlet Temperature of the condenser where the refrigerant eject as saturated liquid

T4= Inlet temperature of the compressor where the liquid enters as dry saturated vapour

The dryness fraction for point two is zero and point four is one

$\mathrm{X} 2=0 ; \quad \mathrm{X} 4=1 ; \mathrm{m}=0.03 \mathrm{Kg} / \mathrm{sec}$

$\mathrm{Hf} 3=\mathrm{H} 4$

Where $\mathrm{H}$ is the enthalpy $\mathrm{kJ} / \mathrm{kg}$

And the pressure $\mathrm{P} 3=\mathrm{P} 2$

From the steam table Properties of R-22 refrigerant and the enthalpy can be taken at specific temperature and pressure. The refrigeration effect

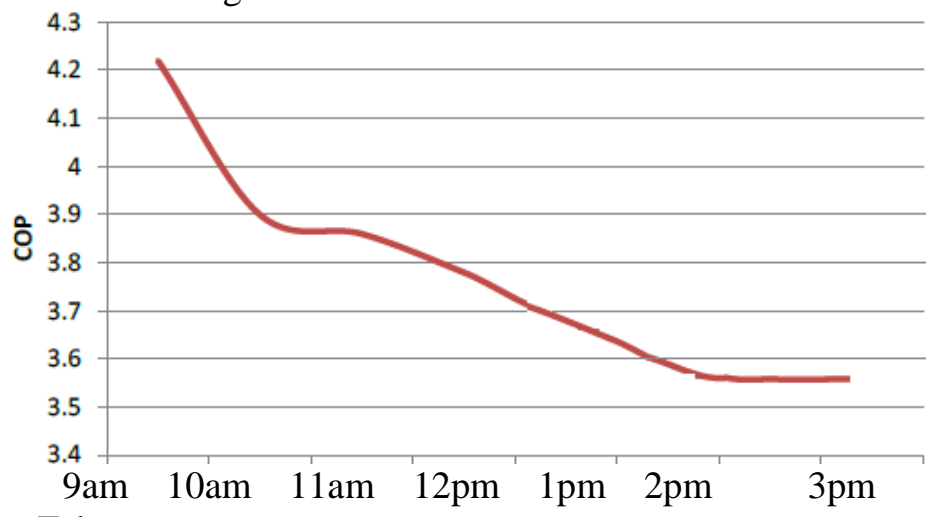

Figure 9: COP during Feb 
Above graph predicts the behavior and the COP which is declining from 9 am till 10 am further the COP gradually decline up to $4 \mathrm{pm}$. This data is related with February month in Hyderabad-Telangana in this region dawn is cool.

cop

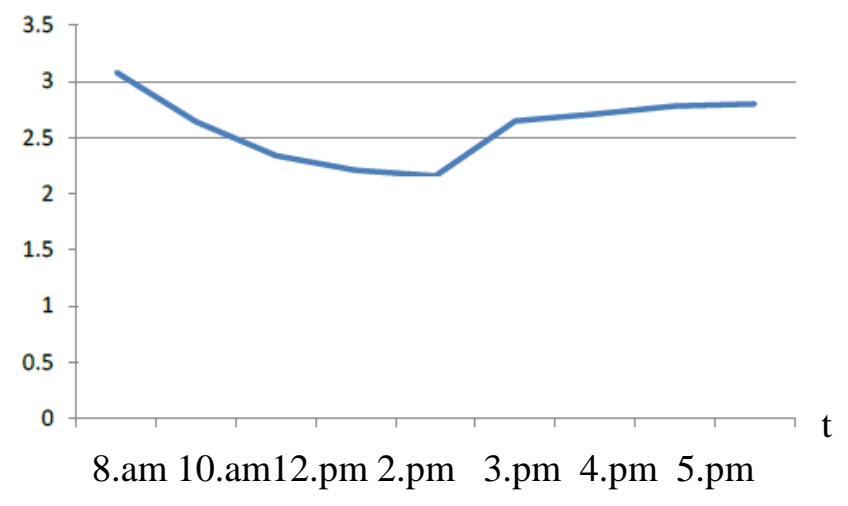

Fig : COP during April/May

Onset of summer begins in the month of April and trails by end of May. The above figure demonstrates the COP of the system related to a working day in this duration.

The above graph which is plotted as time vs. Temperature during peak hours of the day for the above said duration it depicts the COP of the system is at the lowest level due to scorching summer and dense occupancy in the offices.

\section{CONCLUSIONS}

The theme and the ambition of this research are to provide alternative solution for the power crises by the newly formed Telangana state. Here the renewable, nonpolluting and widely available solar energy has been suggested to be utilized during summer where the demand for the power is on peak so, to shed the load on electrical grade of the power distribution agency.

It has concluded that the air-conditioning system in government and private sector which is on up rising demand by leaps and bounds is a major threat to the present energy crises in this state. It is estimated that, it may consume $30 \%$ of the present available conventional energy source. Hence it can be shouted out by adopting solar powered air-conditioning.

\section{REFERENCES}

[1] Sayigh, A.A.M. (1981) Solar Air Conditioning in a Hot Arid Climate. Proceedings of the Second Miami International Conference, Miami Beach, 10-13 December 1979, 761-773.

[2] Mattarolo, L. (1982) Solar Powered Air Conditioning Systems: A General Survey. International Journal of Refrigeration, 5, 371-379.

[3] Bong, T.Y, Ng, K.C. and Tay, A.O. (1987) Performance Study of a Solar-Powered AirConditioning System. Solar

Energy, 39, 173-182.

[4] Aly, S.E. and Fathalah, K.A. (1988) Combined Absorption-Desiccant Solar Powered Air Conditioning System. WärmeundStoffübertragung, 23, 111-121.

[5] Yeung, M.R., Yuen, P.K., Dunn, A. and Cornish, L.S. (1992) Performance of a Solar-Powered Air Conditioning System in Hong Kong. Solar Energy, 48, 309-319.

[6] Tsilingiris, P.T. (1993) Theoretical Modelling of a Solar Air Conditioning System for Domestic Applications. Energy 
Conversion and Management, 34, 523-531.

[7] Khalid Ahmed, C.S., Gandhidasan, P. and Al-Farayedhi, A.A. (1997) Simulation of a Hybrid Liquid Desiccant Based

Air-Conditioning System, Applied Thermal Engineering, 17, 125-134.

[8] Li, Z.F. and Sumathy, K. (2000) Technology Development in the Solar Absorption AirConditioning Systems. Renewable and Sustainable Energy Reviews, 4, 267-293.

[9] Moncef, B., Chahbani, M.H. and Amenallah, G. (2005) Solar Powered Air Conditioning as a Solution to Reduce Environmental Pollution in Tunisia. Desalination, 185, 105-110.

[10] Mittal, V., Kasana, K.S. and Thakur, N.S. (2005) The Study of Solar Absorption AirConditioning Systems. Journal of

[11] Sayegh, M.A. (2007) The Solar Contribution to Air Conditioning Systems for Residential Buildings. Desalination, 209,

171-176.

[12] Constantinos, A., Gershon, G., Hans-Martin, H., Carlos, A., Infante, F., Erich, P., Wang, L. and Edo, W. (2007) Solar Air Conditioning in Europe-An Overview. Renewable and Sustainable Energy Reviews, 11, 299-314.

[13] Zhai, X.Q., Wang, R.Z., Wu, J.Y., Dai, Y.J. and Ma, Q. (2008) Design and Performance of a Solar-Powered Air-Conditioning System in a Green Building. Applied Energy, 85, 297-311.

[14] Umberto, D., Stefania, P. and Paolo, S. (2009) Solar-Powered Cooling Systems: Technical and Economic Analysis on Industrial Refrigeration and Air-Conditioning Applications.Applied Energy, 86, 1376-1386.

[15] Naukkarinen, P. (2009) Solar Air Conditioning and Its Role in Alleviating the Energy Crisis of the Mediterranean Hotels. International Journal of Sustainable Energy, 28, 93-100.

\section{BIOGRAPHIES}

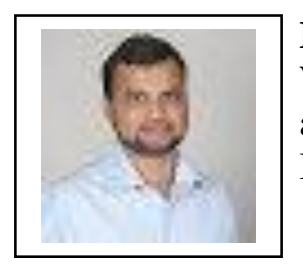

Mohammed ArifHussain,M.Tech , Working in Mechanical Department as Professor in Guru Nanak Institutions Technical Campus

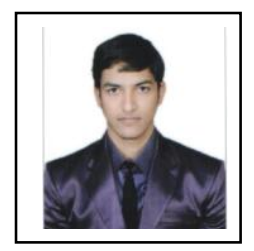

Mr Mohammed DilawarM.Tech , Working in Mechanical Department as an Assistant professor in Guru Nanak Institutions Technical

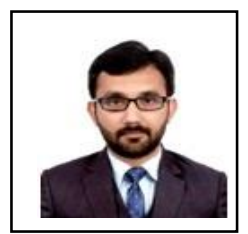

Campus

Mohammed Akram Ullah Khan, working in Civil Department as an Assistant professor in Guru Nanak Institutions Technical Campus 